\title{
Application of Multisensory in Learning Alphabets Identification Skills for Special Education Students
}

\author{
Noor Syamilah Bt Md Maliki ${ }^{a}$, Mohd Hanafi Mohd Yasin ${ }^{\mathrm{b}}$ \\ ${ }^{a}$ Sekolah Kebangsaan Parit Keroma Darat, 84000 Muar, Johor, Malaysia.

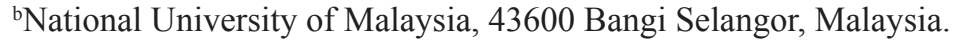 \\ E-mail : mimiesyamilah@gmail.com
}

\begin{abstract}
Multisensory is a method of learning and teaching which integrates all sensories. The objective of this study is to determine the level of progress in learning alphabets identification skills after the application of the multisensory method in special education learning for children with learning disabilities. This study is conducted using a quasi-experimental approach upon six students with learning disabilities who are selected by way of purposive sampling. The students are divided into two groups. Group A is the treatment group while Group B is the control group. The students in Group A receive learning intervention through multisensory while the students in Group B receive learning through traditional teaching methods. Both teaching methods are carried out for a period of four weeks. The research instruments consist of pre-test and post-test adapted from Clay (2005) Observation Survey of Early Literacy Achievement. The results are analyzed descriptively by way of mean and percentages. The research results show improvement of the test scores of the treatment group as compared to the control group. This indicates that the multisensory method is effective and appropriate to be applied in relation to children with special needs due to their learning disabilities in terms of alphabets identification.
\end{abstract}

Keywords: multisensory, learning disabilities.

Reading is one of the ways of acquire knowledge. Even in the first revelation received by Prophet Muhammad s.a.w through the archangel Gabriel, he was asked to read by the call of Iqra', which carries the meaning 'read' or 'recite' (Surah Al-Alaq: 1-5).

Through reading, one can acquire information which can be utilised in his or her life (Tamam et al., 2010). Hence, difficulties in reading will hamper a person's ability to gather information and knowledge that can be used in their everyday life. Reading is a skill which is compulsory to be taught to special education students with learning disabilities. This is in line with the Standard Primary School Curriculum (KSSR) for students with learning disabilities where for Bahasa Melayu, the students are required to recognise the sound of and be able to recite the alphabets from a to $\mathrm{z}$.

The Education Act 1996 and the Education (Special Education) Regulations (2013) stipulate that students who have been certified by a medical practitioner, an optician, an audiologist, or a psychologist as having disabilities in terms of sight, hearing, speech, physical disabilities, learning disabilities, or a combination of any of these can be defined as students with special education needs. Therefore, students who fall within this category are entitled to undergo their education in any educational institutions. Teachers who teach students with special educational needs can conduct lessons upon making the necessary adjustments to their teaching methods and techniques, their time, the schedule of activities and the teaching aid materials based on what is appropriate, as long as they do not conflict with the Special Education Curriculum.

The learning disabilities faced by special education students propel them towards the inability to remember and recognise alphabets. Given that students with learning disabilities have varying levels of proficiency, the special education teacher should prepare appropriate and effective educational activities, tailored to their individual level of abilities. According to Yahya et al. (2012), knowledge on teaching and learning materials must be upgraded from time to time. Therefore, teachers need to continue to improve their teaching skills by planning and choosing educational activities more creatively in order to stimulate their students' potential growth, talents, abilities, and to spark their interest in learning.

Adjustments to techniques and methods of learning can be made to assist students with various problems in special education class. Ghani \& Aznan (2010) stated that students with learning disabilities require teaching methodologies which encourage the process of interaction. This in turn depends on the teacher's capacity and ability to identify the student's behaviour. In view of this, teachers need to have a good grasp of several teaching methods or techniques which can help students to master the topic of learning. 


\section{Diagram 1. Conceptual Diagram on the Application of Multisensory}

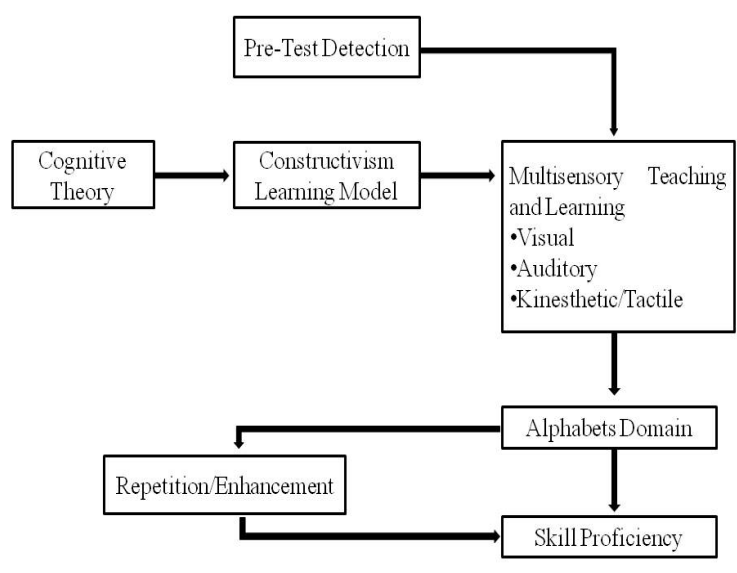

Teachers must also be wise when dealing with students' behaviour during classroom sessions. According to Rita et al. (2002), every child can master a topic of learning but each of them would achieve this in their own way according to their individual style of learning. Therefore, a teacher's ability to plan and execute lessons and to capture and maintain their students' attention is crucial. The Minnesota Literacy (2015) claimed that every individual is able to benefit from multisensory learning, especially those suffering from learning disabilities and dyslexia, toddlers, and individuals with sensory integration issues. The Minnesota Literacy (2015) also stated that due to the various learning disabilities and learning styles, everyone is entitled to use multisensory approach in order to help these special individuals acquire knowledge.

Multisensory is one of the methods which has been adopted in the application of teaching and learning strategies. Multisensory teaching was developed by several pioneers in the field of education such as Montessori (1912), Fernald (1943) and (Gillingham \& Stillman, 1997), where they have had to teach toddlers and students with learning disabilities such as dyslexics, late learners and those with inability to focus in learning. A few principles are applied as part of the technique to integrate all sensory such as application by the professionally trained, testing using appropriate tests, enhanced sensory activities involving audio and visual, safe intervention areas, engaging activities, activities requiring interaction involving the whole body especially through game-playing, the creation of internal motivation, and activities enjoyed by the students (Parham et al. 2007). The Minnesota Literacy (2015) described multisensory as being educational sessions involving self-sensory, focusing on the use of visual, auditory, and tactile-kinesthetic elements. This method of learning involves multiple sensories which can aid the learning process and activate several sections of the brain. The involvement of these sections of the brain can help to strengthen memory and assist in the learning of language in the written form. It also helps each student with learning disabilities to choose the method which is most suitable for themselves. This way, the approach can channel many other ways of learning, to gain comprehension of new information in order to help them memorise and later re-use the same knowledge again.

Abdullah (2012) conducted a research to study the effectiveness of multisensory learning in dyslexic children, upon discovering that no one specific method was used in helping these children gain Bahasa Melayu language skills. Abdullah (2012) found that this method was able to reduce the problem of reading skills in children with specific learning disabilities in one of four domains, being recognition and confusion of alphabets.

Subramaniam, Mallan, \& Mat (2013) found that multisensory activities are capable of bringing to life an environment which enhances learning, especially wordbased learning. In their efforts to produce a description of multisensory activities for learning alphabets among dyslexic children, they discovered that teachers were often able to conduct multisensory learning sessions after realising the breadth of activities which can be conducted using the multisensory method. They also discovered that multisensory was able to capture students' attention and create an environment which stimulate learning and fun vibes. The concept of 'playwhile-you-learn' inherent in multisensory learning is able to attract and hold the students' attention during classroom sessions. This makes multisensory learning a very suitable approach for use in educating children with special needs, a majority of whom typically have low levels of attention span which disrupt their focus on learning.

Problems with reading skills are often associated with special education students with learning disabilities. This problem can be divided into two categories, namely difficulties in decoding alphabets and difficulties in understanding what is being read (Talib, 2000). According to Whitehurst \& Lonigan (2001), pre-reading skills encompass the ability to observe and recognise alphabets, which usually poses a challenge among students with learning disabilities, whether at a moderate or severe level. Undeniably, teaching special education students to identify and recognise alphabets is a difficult task at hand for teachers to accomplish. Students are able to read effectively if they have successfully acquired reading skills through learning in school (Yahya et al. (2012). It is very challenging for teachers to realise the transfer of this skill without having a suitable method of learning at hand, given that special education students are faced with many different types of problems. 


\section{Diagram 2. Respondents and Locations of Research Study}

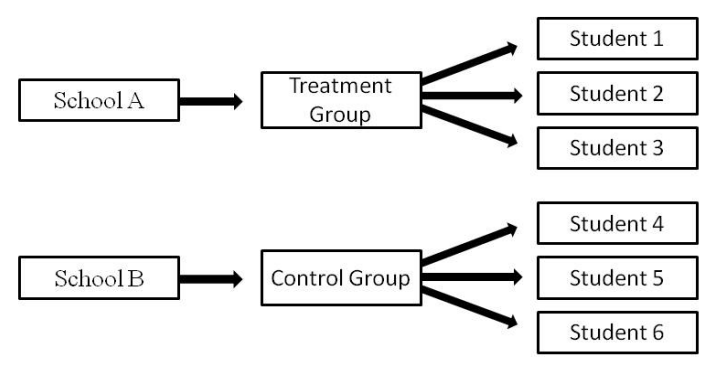

Diagram 3. Comparison between Pre Test and Post Test Scores for the treatment group and the control group.

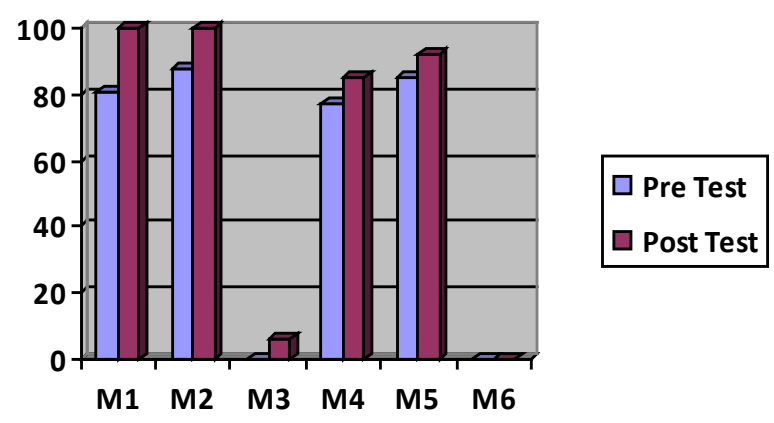

Table 1. Sequence of Alphabets Grouping

\begin{tabular}{cccccc}
\hline \multicolumn{7}{c}{ Capital Letters } \\
\hline A & F & K & P & W & Z \\
B & H & O & J & U & \\
C & Y & L & Q & M & \\
D & N & S & X & I & \\
E & G & R & V & T & \\
\hline \multicolumn{7}{c}{ Small Letters } & & \\
\hline a & f & k & p & w & Z \\
b & h & o & j & u & \\
c & y & l & q & m & \\
d & n & s & x & i & \\
e & g & r & v & t & \\
\hline
\end{tabular}

Thus, this research is conducted to identify whether the multisensory method can help special education children to identify alphabets, which is one of the main reading components in literacy skills. The objectives of this research are: (i) To study the level of success in learning alphabets before and after using the multisensory method. (ii) To identify the effectiveness of using multisensory method in alphabets identification skill activity.

\section{METHOD}

For this research study, a quasi-experimental design is selected. The design of this study is used to evaluate the effectiveness of multisensory method in teaching alphabets identification skills. This design is chosen to replace the experimental design where random sampling cannot be done (Chua, 2006). As highlighted by White \& Sabarwal (2014), the quasi-experimental design requires members of the control group and the treatment group to possess almost identical characteristics during the time before the intervention is carried out. Two groups of respondents are used, one being the control group and the other being the treatment group. The respondents from the control group will receive learning through traditional methods while multisensory learning will be applied to the treatment group.

The respondents in this study are selected from two schools in the Muar district. The location of the study has to be compatible with the selection of respondents, and must be readily accessible and easy to reach. (Othman, 2014). The respondents of this study are selected through sampling based on the researcher's own discretion, where the sample is made up of special education students at primary level. It is suitable for sampling to be used for quasi-experimental research, seeing that the number of sample students with learning disabilities are small, with not much choice available (Chua, 2006).

A total of six students from the special integrated learning programme (PPKI) are selected, all of whom are students with learning disabilities. Three students from the treatment group in School A receive learning intervention which apply multisensory method, whilst the three students from the control group in School B receive learning through traditional teaching methods.

The research instrument used in this study are the pre-test and post-test. These are test questions adapted from Clay (2005) Observation Test of the Level of Early Literacy Achievement.. The questions consist of four parts. The first part is concerned with details of the student, the second part contains instructions requiring students to read out the name of alphabets aloud, the third part contains research instrument questions and the fourth part is a dedicated section for teachers to respond. The tables below show the groupings of alphabets contained in the test instrument.

The pre-test and post-test given to the respondents in this study consist of identical questions. The students are required to say aloud the names of the alphabets shown to them by the teacher. This research is carried out for a duration of four weeks, with lessons being conducted for 180 minutes each week.

Prior to commencement of the research, teachers from the two schools who are involved in this research are briefed by the researcher. 
Table 2. Pre Test and Post Test Score Results in Identification of Alphabets

\begin{tabular}{cccc}
\hline \multicolumn{4}{c}{ Treatment Group } \\
\hline \multirow{2}{*}{ Respondents } & \multicolumn{2}{c}{ Test Scores } & Increase in \\
& Pre & Post & score \\
M1 & 81 & 100 & 19 \\
M2 & 88 & 100 & 12 \\
M3 & 0 & 6 & 6 \\
\hline Min & 56 & 69 & 12.3 \\
\hline \multicolumn{4}{c}{ Control Group } \\
Respondents & \multicolumn{2}{c}{ Test Scores } & Increase in \\
M4 & Pre & Post & score \\
M5 & 77 & 85 & 8 \\
M6 & 85 & 92 & 7 \\
\hline Min & 0 & 0 & 0 \\
\hline
\end{tabular}

The students are selected based on certain criteria determined by the researcher. The preliminary data from the pre-testing are collected in order to evaluate the students' level of proficiency in identifying alphabets. After four weeks of intervention sessions for the treatment group and traditional lessons for the control group, the students are then tested again in the post-test session.

\section{FINDINGS AND DISCUSSION}

The data obtained through the pre-test and post-test are analysed descriptively using percentage and min. The difference between the test scores of the pre-test and the post-test for both groups are displayed in order to evaluate the level of progress in learning alphabets identification skills before and after using multisensory method of learning. The increase in the scores, being the difference between the scores of the pre-test and the post-test, enables comparison to be made in order to clearly see any increase which occurs.

Level of progress in alphabets identification skills before and after using multisensory method.

Diagram 3 shows a comparison between the scores achieved by respondents from the Treatment Group and the Control Group in the pre-test and the post-test. Respondents in M1 dan M2 show an increase in their scores of the post-test, where scores of $100 \%$ are achieved. In M3, there is an increase of $6 \%$ which is the score obtained in the post-test compared to $0 \%$ in the pre-test.

Meanwhile, for respondents in the control group M4, there is increase in score from $77 \%$ to $85 \%$. Similarly, respondents in M5 obtain 92\% score in the post-test compared to only $85 \%$ in the pre-test. However, it is noted that no increase in score can be seen in the test results for M6. The most significant progress in learning alphabets identification skills is achieved by the respondents in the treatment group M1.

\section{Effectiveness of use of multisensory method in activities of learning alphabets identification skills.}

Table 2 records the results reflecting the progress achieved in the identification of alphabets after the intervention sessions have come to an end. In all three treatment groups M1, M2 and M3, the students show progress in their ability to identify alphabets. Meanwhile, two out of three students in the control group also make progress although the scores show no change to one other student's ability to identify alphabets. Respondents in M1 show improvement by 19 per cent, M2 by 12 per cent and M3 by 6 per cent. For the respondents in M4, 8 per cent progress is made, followed by 7 per cent for M5 and 0 per cent for M6. The highest average of the increase in the post-test scores is displayed by the treatment group at 12.3 per cent, compared to only 5 per cent for the control group.

Analysis of the research results finds that students with learning disabilities who receive multisensory intervention in teaching and learning show improvement in their ability to identify alphabets. These students participated in several educational activities which involved the use of their various senses during lessons on identifying alphabets. The test scores show that multisensory method is able to help students achieve progress in their learning. The outcome of this research study also indicate that learning activities which apply multisensory activities are more effective compared to the traditional learning method. This is consistent with Dalecki (2007) who claimed that multisensory can increase the number of alphabets and words learnt by children. This is also in line with the results obtained by Abdullah (2012) and Subramaniam, Mallan, \& Mat (2013) where the use of multisensory in leaarning and teaching is shown to be able to help with the progress in learning for special education students, especially in teaching alphabets identification skills in the Malay language.

\section{CONCLUSION AND SUGGESTION}

Based on the results obtained, it can be concluded that multisensory learning can increase students' ability of to acquire the skill of alphabet identification. Teachers have to be ready to equip themselves with knowledge on teaching and learning in order to help students with special needs to elevate their learning capabilities. Their ability to read and understand what they are reading can be enhanced once their struggles with learning alphabets are overcome. This study is also a follow-up initiative as part of the efforts to clarify the teachers' understanding of multisensory and 
of suitable activities which can be carried out during teaching and learning sessions in the classroom.

It is hoped that research studies such as this can continue to be conducted, by matching student's learning styles with the appropriate multisensory learning activities. Further, research concerning multisensory learning activities can be expanded to include other subjects related to special education, such as self-management which has proven to be essential for students with special education needs. Other recommendations would be to prepare a listing of activities or to produce a module on multisensory as part of the efforts to provide teachers with the necessary guidance in their teaching activities.

\section{REFERENCES}

Abdullah, M. (2012). Keberkesanan Kaedah Multisenori Dalam Pengajaran Dan Pembelajaran Bahasa Melayu Kanak-Kanak Disleksia (Doctoral dissertation, Universiti Kebangsaan Malaysia).

Chua, Y. P. (2006). Kaedah Penyelidikan Buku 1. McGraw (Malaysia)Sdn. Bhd.

Clay, M. M. (2005). An observation survey of early literacy achievement (2nd ed.). Portsmouth, NH: Heinemann Education

Dalecki, C, G. (2007). Improving Letter and Word Recognition Using a Multisensory Approach. Education and Human Development Master's Theses. Paper 282.

Fernald, G. (1943). Remedial techniques in basic school subjects. New York:McGraw-Hill.

Ghani, M. Z., \& Aznan, C. A. (2010). Strategik pengajaran kanak-kanak berkeperluan khas. Pulau Pinang: Penerbit USM

Gillingham, A., \& Stillman, B. W. (1997). The Gillingham manual: Remedialtraining for children with specific disabilityin reading, writing, and penmanship(8th ed). Cambridge, MA:Educators Publishing Service.

Literacy, C. (2015). Multisensory Activities to Teach Reading Skills Minnesota. Summer Reads

Montessori, M. (1912). The Montessori Method. , New York.

Othman, L. (2014). Penyelidikan kualitatif: Pengenalan kepada teori dan metode. Tanjong Malim: Penerbit Universiti Pendidikan Sultan Idris

Rita, D., Jeffrey, S. B., \& Angela, K. (2002). Survey of Research on Learning Style. Carlifonia Journal of Science Education, 2(2), 75-98.

Subramaniam, V., Mallan, V. K., \& Mat, N. H. C. (2013). Multi-senses explication activities module for dyslexic children in Malaysia. Asian Social Science, 9(7), 241.
Talib, A. A. A. (2000). Pedagogi bahasa Melayu: prinsip, kaedah, dan teknik. Utusan Publications \& Distributors.

Tamam, T., Zamri, M., Nik, M. R. Y. \& Jamaludin, B. (2010). Masalah Membaca Murid-murid Sekolah Rendah Kerajaan di Brunei Darussalam: Satu Kajian Kes. Jurnal Pendidikan Malaysia, 35(2), 77-85.

Whitehurst, G. J., \& Lonigan, C. (2001). Emergent literacy: Development from prereaders to readers. Dlm. S. Neuman \& D. Dickinson (Eds.). Handbook of early literacy research, 11-30. New York: Guilford.

Yahya, O., Asiah, M. D., \& Azmey, O. (2012). Pelaksanaan Pengajaran Membaca Menggunakan Kaedah Fonik Peringkat Prasekolah di Brunei Darussalam. Jurnal Pendidikan Bahasa Melayu, 2(1), 93-109. 